\title{
State and Trends of Occupational Health and Safety in the Philippines
}

\author{
Jinky Leilanie Lu, MOH, PhD \\ National Institutes of Health, University of the Philippines Manila
}

\begin{abstract}
Introduction. In the Philippines, industries began to recognize the importance of workers' health after occupational safety and health were introduced in the early 1900s. Ever since, several legal bases have existed to protect the people's welfare. However, data regarding this matter is limited in the country.
\end{abstract}

Objective. This paper aimed to develop a comprehensive review of occupational safety and health data, including hazard exposures and occupational diseases for various Filipino occupational groups.

Methods. A comprehensive analysis of the latest records and statistics from various government agencies, nongovernment organizations, academe, and research institutions was done. Data analysis was completed through a critical appraisal of the Philippines' current occupational health and safety regarding occupational diseases, injuries, accidents, and existing occupational health and safety policies. Data were also extracted from reviews of literature and other related research studies. Data analysis was done through a critical appraisal of the Philippines' current occupational health and safety in terms of occupational diseases, injuries, accidents, and existing occupational health and safety policies.

Results. Most of those working in the informal sectors do not have enough social protection in the Philippine context. Others in the same situation involve construction workers, farmers, miners, and waste or garbage pickers. Child labor was also seen to be prevalent, risking these children's health and safety. Another issue is on gender, and wherein women were found to have lesser protection than their counterparts. Among the industries present in the country, administrative and support service activities, manufacturing, wholesale and retail trade, financial and insurance activities, education except for public education, and agriculture, forestry, and fishing were seen to have a high prevalence of occupational diseases. The study has shown occupational safety and health among various occupational groups and categories, the profile of occupational diseases in Philippine industries, and the OSH programs implemented in industries.

Conclusion. Analysis of available data confirmed the presence of threats of unsafe and unhealthy conditions in various jobs and workplaces. To keep up with other nations, the country should strive more with its local developments.

Key Words: Occupational Safety and Health, occupational diseases and injuries

\section{INTRODUCTION}

Corresponding author: Jinky Leilanie Lu, MOH, PhD National Institutes of Health

University of the Philippines Manila

623 Pedro Gil St., Ermita, Manila 1000, Philippines

Email: jdlu@up.edu.ph / jinky_lu@yahoo.com
The introduction of occupational safety and health in the Philippines dates back to 1903 where industries provided health services to treat their employees' injuries and diseases. ${ }^{1}$ From then on, establishments and the government have started to recognize the importance of the health of their workers for them to be more productive at work. For instance, in 1936, the Commonwealth Act No. 104, also known as the First Industry Safety Law, aimed to protect and ensure the safety of workers in mines, quarries, and metallurgical operations. In 1954, the Republic Act 1054, also known as the Free Medical and Dental Law, mandated that emergency 
health interventions must be provided to workers. To protect the welfare of Filipino workers, there must exist a legal basis of occupational safety and health laws. Thus, Presidential Decree No. 442, otherwise known as the Labor Code of the Philippines, integrating occupational safety and health was promulgated.

According to the latest estimates of the International Labor Organization in 2017, there are around 2.78 million people who die annually due to occupational diseases and accidents, and 2.4 million of which are caused by occupational diseases. Also, almost 374 million are affected by non-fatal occupational accidents. ${ }^{2}$ On the other hand, the World Health Organization (WHO) estimated that 12.2 million people, especially those in developing countries, die from non-communicable diseases (NCDs) while still belonging to the productive or working age. Many occupational risks and hazards exist worldwide in different industries, such as injuries, noise, carcinogens, airborne particles, ergonomic hazards, and others. ${ }^{2}$ These contribute to the burden of chronic diseases, including back pain (37\%), hearing loss (16\%), chronic obstructive pulmonary disease (13\%), asthma (11\%), injuries (8\%), lung cancer (9\%), leukemia (2\%), and depression (8\%). ${ }^{3}$ Meanwhile, work-related accidents and injuries likely occur in high-risk jobs involving mining, construction, agriculture, and manufacturing activities. ${ }^{4}$ It was also found that Asia (65\%) - where the Philippines is situated has the most significant number of mortality and morbidity related to work, followed by Africa (11.8\%), Europe (11.7\%), America (10.9\%), and Oceania (0.6\%). ${ }^{2}$ These occupational accidents and diseases negatively affect the economy. In 2017, four percent of the total GDP of around US\$ 3 trillion was lost every year because of lost working time, interruptions in production, treatment of occupational injuries and diseases, rehabilitation, and compensation to injured workers. ${ }^{5}$

In the Philippine setting, it is only estimated that 2.2 million Filipino workers in medium and large enterprises enjoy effective occupational safety and health (OSH) protection and services. This means that 17 of 18 persons in the nation's workforce of 38.8 million do not have acceptable working conditions and are exposed to hazards that predispose them to occupationally related diseases and injuries. ${ }^{6}$ Labor and employment statistics show that a significant proportion of the population engaged in productive work. The total population of the Philippines reached 100,981,437 by 2015. ${ }^{7}$ However, it was expected by POPCOM to increase up to 110.8 million at the onset of the year 2021). ${ }^{8}$ The Philippines has a GDP of US\$ 313.6 billion with recent annual growth of $6.0 \%$ in $2019 .{ }^{9,10}$ The country's labor force declined by $2.7 \%$ from $61.4 \%$ in 2019 to $58.7 \%$ in 2020 . The employment rate decreased by $4.1 \%$ from $95.4 \%$ in 2019 to $91.3 \%$ in 2020 , whereas the unemployment rate increased from $4.6 \%$ (2019) to $8.7 \%$ (2020). The underemployment rate increased by $1.6 \%$ from $12.8 \%$ in 2019 to $14.4 \%$ in 2020, warranting a national concern. ${ }^{11}$ The Philippines has a relatively young population and a young workforce. As of
$2020,27.6 \%$ of the total number of employed persons were 25-34 years old. This was followed by ages 35-44 years old at $24.0 \%$ and $45-54$ years old at $19.3 \% .^{12}$ In January 2021 , the number of employed males (73.9\%) dominated the females (46.9\%). The same is true regarding the underemployment rate, and wherein there is a $4.2 \%$ gap between males $(17.6 \%)$ and females (13.4\%). ${ }^{13}$

Occupational health and safety in the Philippines are enshrined in the Philippine Constitution as its legal framework, which embodies the rights of employees to gainful, participatory, healthy, safe, and just employment. ${ }^{6}$ Labor Code, on the other hand, ensures that the rights of the workers are protected. The Labor Code of the Philippines has seven (7) books, and Book 4 embodies the regulations and guidelines on health and safety at work in the Philippines. ${ }^{7}$ The national framework for Occupational Safety and Health in the Philippines includes the constitution, labor code, department orders, and company policy and program bipartite (Table 1). Based on the principles and stipulations of the Constitution and the Labor Code, there are corresponding administrative and department orders to facilitate tripartite dialogue among management, labor, and government. The company policy and occupational health and safety program focused on the bipartite dialogue between management and labor-management councils and the OSH committee. ${ }^{8}$

Occupational Health and Safety in the Philippines is a mandate of various government agencies based on the four structures of occupational safety in the Philippines. Occupational Safety and Health Center (OSHC) through EO 307 is concerned with the preventive aspect of OSH. The enforcement of OSH and its related standards is under DOLE Regional Officers' mandate through Admin Code 1987. The same code governs the development and updating of OSH policies mandated under the DOLE Bureau of Working Conditions. Lastly, PD 626 created the Employees Compensation Commission for the compensation and Rehabilitation structure of OSH. ${ }^{8}$

Table 1. National Framework for Occupational Safety and Health in the Philippines

\begin{tabular}{|c|c|c|}
\hline & Origin & Enforcement \\
\hline Constitution & $\begin{array}{l}\text { Constitutional } \\
\text { Convention }\end{array}$ & Supreme Court \\
\hline $\begin{array}{l}\text { Labor Code Specific } \\
\text { Laws (OSH standards) }\end{array}$ & Congress & $\begin{array}{l}\text { NLRC, DOLE, } \\
\text { Courts }\end{array}$ \\
\hline $\begin{array}{l}\text { Department Orders } \\
\text { (Construction, drugs, } \\
\text { TB, HIV/AIDS, Hep } \\
\text { B, maritime, etc.) }\end{array}$ & $\begin{array}{l}\text { Tripartite Dialogue } \\
\text { (management, labor, } \\
\text { government) }\end{array}$ & DOLE, Courts \\
\hline $\begin{array}{l}\text { Company Policy and } \\
\text { Program (bipartite) }\end{array}$ & $\begin{array}{l}\text { Management, Labor } \\
\text { Collective bargaining } \\
\text { agreements, labor- } \\
\text { management councils, } \\
\text { OSH committees }\end{array}$ & $\begin{array}{l}\text { Internal Monitoring } \\
\text { (Bipartite) } \\
\text { Joint Labor- } \\
\text { Management } \\
\text { Grievance Procedure }\end{array}$ \\
\hline
\end{tabular}

DOLE = Department of Labor and Employment NLRC = National Labor Relations Commission 
This paper aimed to show a comprehensive review of data on occupational safety and health in the Philippines.

\section{METHODOLOGY}

The study also extracted data sources and statistical records from government agencies, academe and research institutions, and non-government organizations. The methodology consists of a comprehensive analysis of the latest documents and statistics on occupational safety and health and related variables from the Integrated Survey of Labor and Employment (ISLE) under the Philippine Statistics Authority (PSA), which is a new government authority created from four former national agencies namely the National Statistics Office (NSO), National Statistical Coordination Board (NSCB), Bureau of Agricultural Statistics (BAS), and Bureau of Labor and Employment Statistics (BLES); as well as from the Occupational Safety and Health Center (OSHC), International Labor Organization (ILO); World Health Organization (WHO), and non-government organizations. Data were also extracted from reviews of literature and other related research studies. Data analysis was done through a critical appraisal of the Philippines' current occupational health and safety in terms of occupational diseases, injuries, accidents, and existing occupational health and safety policies.

This paper aimed to develop a comprehensive review of data on occupational safety and health in the Philippines. A complete data on occupational safety and health in the Philippines, including hazard exposures and occupational diseases for various occupational groups, can provide an understanding to stakeholders, both private industries and the government bodies, to improve the health and safety conditions of the workers. This will also enable concerned industries and entities where the gaps in OSH are, and corollary intervention measures can be crafted and implemented.

This study deals with online resources, grey literature, and various statistics from government agencies. A sampling of population or sampling frame was not warranted. All study covers 2012-2017 (latest data and statistics available on OSH in the Philippines). This has its merit as a descriptive analysis of the status of OSH in the Philippines. The research question being pursued in this paper is- What is the quality of Occupational Safety and Health in the Philippines, covering three domains of variables- 1.) OSH of various occupational groups and categories; 2.) Occupational Diseases and Hazards in Industries in the Philippines; and 3.) Occupational Safety and Health Standards and Programs in Philippine Industries.

\section{RESULTS}

\section{OSH of various Occupational Groups and Categories}

\section{The Informal Sector}

The majority of workers belong to the informal sector in many countries, especially developing countries. The informal sector is characterized by minimal social protection, including non-provision of proper health care and the enforcement of occupational health and safety standards. ILO stated that independent, self-employed small-scale producers and goods and services distributors comprise the informal economy. ${ }^{14}$ According to the National Statistical Coordination Board (NSCB) Resolution No. 15 in the Philippines, the informal sector is officially referred to as "household unincorporated enterprises which consist of both own-account enterprises and enterprises of informal employers." Own-account enterprises are household enterprises owned by own-account workers, alone or in partnership with member/s of the same or other households. They employ occasionally or seasonally hired workers but not continually.

On the other hand, enterprises of informal employers are almost the same as the own-account enterprises except that the latter employs one or more workers frequently. Employees in corporations, quasi-corporations, units with more than ten employees, corporate farms, commercial livestock raising, and commercial fishing are excluded in the informal economy. ${ }^{15}$ Labor relations in this sector are under the basis of casual employment, kinship, or personal and social relations instead of formal or contractual arrangements. ${ }^{16} \mathrm{~A}$ study under OSHC showed that the working conditions of jeepney drivers, market vendors, and tricycle drivers - selfemployed workers - are poor, with exposure to extreme heat, air pollutants, biological agents, and ergonomic risk factors.

\section{Farmers}

Farming is considered one of the critical and most prevalent income-generating activities in the Philippines; it is even supposed to be a generational occupation because almost all family members are involved in farming and its related activities. The agriculture and fishing sector is vital in the Philippines's economy as it contributed $8.49 \%$ to the country's Gross Domestic Product, registering a 4.01\% increase in the year $2017 .{ }^{17}$ It also has contributed to $25 \%$ of the country's total employment employing about 10.26 million workers out of the 40.33 million total workers in $2017 .{ }^{18}$ This, however, dropped to $24.4 \%$ in January $2021 .{ }^{13}$ The Filipinos are inclined to get into farming, a fishing job or both which needs stricter monitoring of occupational safety and health conditions because this sector presents different types of occupational risks and hazards. There is extensive use of pesticides among Filipino farmers; in fact, the Philippines is one of the Southeast Asian countries recorded with the highest usage of pesticides for farming. ${ }^{19}$ Two different studies by Lu showed that farmers are exposed to pesticides and their harmful effects. Farmers in Benguet and Pangasinan showed adverse health effects of pesticide exposure, including easy fatigability, decreased appetite and weight, dermal itchiness, eye redness, muscle pains, headaches, and abnormal laboratory findings. ${ }^{20,21}$ There were even death reports in the country caused by pesticide poisoning. ${ }^{19}$ In addition to these, this sector is dangerous as it requires long working hours, 
exposing farmers to cuts, injuries, and harmful chemicals such as pesticides. ${ }^{22}$ In response to observations of farmers having lung problems after using commercial fertilizers and pesticides, a city in Ilocos Sur mobilized farmers to shift to organic farming and eliminate the use of chemicals. ${ }^{23}$

Other occupational risks associated with farming are biological risks such as parasitic infections. Schistosomiasis is considered endemic in the Philippines, and farmers have acquired these diseases from water-contaminated farm areas. $^{24,25}$ Lymphatic Filariasis is also prevalent among male adults who farm in abaca plantations as the disease's vectors breed and inhabit the axilla of abaca plants. ${ }^{26}$ Besides this, farmers may contract skin infections such as dermatitis because of exposure to certain tropical plants with an irritant or allergic properties. ${ }^{27}$

\section{Miners}

Miners, especially those employed in small-scale or artisanal mining, face several hazards and risks associated with their job. This industry is characterized by laborious work, simple and traditional tools, and dangerous working conditions. Inadequate lighting and ventilation and exposure to toxic chemicals like mercury and cyanide are examples of workplace hazards that miners encounter. ${ }^{28,29} \mathrm{~A}$ study by $\mathrm{Lu}$ showed that small-scale miners were exposed to dangerous chemicals, including mercury and cyanide. The most-reported health problems of small-scale miners were hypertension and heart diseases. Dermatitis and peripheral neuropathy, which were typical symptoms of cyanide poisoning, were also reported. Risks of falls due to the absence of scaffolds, manual extraction activities, handling of explosive tools, dark underground areas, and exposure to noise and dust were some of the unsafe conditions that miners have to deal with while working. ${ }^{30}$ For large-scale miners, the most common accidents were contusions and lacerations, while respiratory infections and skin irritations are the most common disease diagnoses. ${ }^{31}$ An accident in one of the largest coal-producing mining companies in the Philippines became an issue as some of their miners were buried alive when one of their mining pits collapsed. ${ }^{32}$

\section{Waste or Garbage Pickers}

In many developing countries such as the Philippines, waste or garbage pickers handling solid wastes are faced with several work-related health hazards and risks associated with the type and content of materials handled, equipment and tools used, and the harmful substances emitted by things they managed. Some of these are neglected medicine, hospital and healthcare wastes, and dead animals. ${ }^{33,34}$ The risk further increased during the COVID-19 pandemic, wherein the percentage of healthcare waste generated dramatically increased by $496 \%$ compared to its prepandemic counterpart. ${ }^{34}$ Adverse health effects are likely to occur secondary to these workers' unhygienic and unsafe working conditions. The workers are exposed to materials with inadequate personal protective equipment like gloves, facemasks, goggles, and safety attire. ${ }^{35}$ These risks may be adequately managed by developed countries; however, the opposite is happening in developing countries as there is low saliency and limited resources available for solid waste improvement. ${ }^{36}$

In the Philippines, thousands of Filipino workers informally collect, segregate, and sell solid wastes. Most garbage or waste pickers are included in the informal waste sector, and they are primarily found in dumpsites and collect trash from neighbors and households. The majority of these informal waste or garbage pickers are migrants who lack opportunities and properties. They often are found in informal settlements trying to make ends meet by engaging in jobs with little and unstable income, such as waste picking, handling, and or/collecting. ${ }^{37}$ The most common hazard encountered by waste pickers is the presence of sharp objects..$^{36,38}$ Osteomuscular disorders, arboviruses, intestinal diseases like diarrhea and constipation, hypertension, bronchitis, intestinal worms, breathing issues, sore throat, and diabetes are the usual diseases of the said population and that some of which can be linked to their poor living and working conditions (such as the minimal access to clean water supply). ${ }^{33,38}$ Light wounds, insect bites, and eye irritation were the most common injuries reported by waste pickers. Due to their laborious work, discomfort is most commonly felt in their shoulders, hips/ buttocks, and thighs. The workers are also at a very high risk of developing musculoskeletal disorders (MSD) due to their posture in grabbing waste. ${ }^{35}$

\section{Child Labour}

Child labor has been a serious problem in the Philippines. Child labor is defined as the illegal employment of children below 15 to 18 years old in dangerous occupations. ${ }^{39}$ This may also refer to any economic activity of children under 18 years old that predisposes them to exploitation and is harmful to their health and safety and physical and psychological development. ${ }^{40}$ According to the Annual Poverty Indicator Survey results of PSA in 2019, around 7.6\% (1.19 million) of the 15.64 million families with members aged 5 and 17 years old had a working child. ${ }^{41}$ In the latest 2017 data on Philippine child labor, the total working children are 1.3 million, which is relatively lower than the figures in 2011; still, the age group of 15 to 17 has the most significant population of working children (894,000 children) (Tables 2 and 3). ${ }^{42}$ In terms of residence, rural areas (9.5\% or 745,000 households) have a higher rate of families with working children than urban areas $(5.7 \%$ or 442,000 households). Child laborers are common in agriculture, services, and industry sectors. ${ }^{43}$ According to a recent ILO report, around 152 million are in child labor globally, and 73 million of them do hazardous work. ${ }^{44}$ Hazardous work is defined as work wherein a child laborer is exposed to occupational risks threatening children's health, safety, and moral values. ${ }^{44}$ In addition, due to the economic and social crisis brought by the COVID-19 
Table 2. Child Labor in the Philippines according to Sex and Age, 2017

\begin{tabular}{|c|c|c|c|c|c|}
\hline $\begin{array}{l}\text { Sex and } \\
\text { Age Group }\end{array}$ & $\begin{array}{c}\text { Total household } \\
\text { population of children } \\
(000)\end{array}$ & $\begin{array}{l}\text { Total working } \\
\text { children }(000)\end{array}$ & $\begin{array}{l}\text { Economic activity rate of } \\
\text { children as a percentage of } \\
\text { children population (\%) }\end{array}$ & $\begin{array}{l}\text { Working children not } \\
\text { currently attending school } \\
(000)\end{array}$ & Percentage (\%) \\
\hline Both Sexes & 29,398 & 1,344 & 4.6 & 526 & 39.1 \\
\hline $5-9$ & 11,448 & 57 & 0.5 & 1 & 1.8 \\
\hline $10-14$ & 11,289 & 393 & 3.5 & 56 & 14.2 \\
\hline $15-17$ & 6,661 & 894 & 13.4 & 569 & 52.5 \\
\hline Male & 15,153 & 907 & 6.0 & 425 & 46.9 \\
\hline 5-9 & 5,883 & 30 & 0.5 & 1 & 3.3 \\
\hline $10-14$ & 5,808 & 241 & 4.1 & 47 & 19.5 \\
\hline 15-17 & 3,462 & 636 & 18.4 & 378 & 59.4 \\
\hline Female & 14,245 & 438 & 3.1 & 101 & 23.2 \\
\hline 5-9 & 5,566 & 27 & 0.5 & 1 & 3.7 \\
\hline $10-14$ & 5,480 & 152 & 2.8 & 9 & 5.9 \\
\hline $15-17$ & 3,199 & 258 & 8.1 & 92 & 35.7 \\
\hline
\end{tabular}

Source: Adapted from Philippine Statistics Authority, Statistics on Working Children, 2019

Table 3. Percent Distribution of Working Children 5-17 Years Old by Major Industry Group and Sex, Philippines: 2017 (In Percent)

Industry $\quad$ Both Sexes (\%) Male (\%) Female (\%)

\begin{tabular}{lrrr} 
Agriculture, Hunting, and & 42.3 & 50.8 & 24.5 \\
Forestry & & & \\
Fishing & 4.8 & 6.7 & 0.9 \\
Mining and Quarrying & 0.7 & 0.9 & 0.5 \\
Manufacturing & 5.4 & 5.4 & 5.5 \\
Construction & 4.2 & 6.2 & - \\
Wholesale and Retail Trade & 28.5 & 19.7 & 46.8 \\
Other Service Activities/ & 6.7 & 2.5 & 14.2 \\
Activities of Household & & & \\
as Employers & & & \\
Other Industries Not & 7.7 & 7.7 & 7.8 \\
Elsewhere Classified & & & \\
\hline
\end{tabular}

Source: Adapted from Philippine Statistics Authority, Statistics on Working Children, 2019

pandemic started in 2019, around 42-66 million children are estimated to fall under the category of extreme poverty in the next coming years. ${ }^{45}$ These numbers can be attributed to the massive education disruption, household job loss, and health shocks. In a review about child labor in developing countries, including the Philippines, it was found that around 200 million were in child labor, and 20 million of them were subjected to forced labor. The primary concerns identified in the review were physical exposures such as ergonomic hazards, chemical hazards, and absenteeism at school. ${ }^{46}$ Chemical hazards include possible mercury poisoning in gold mining. During an investigation in Camarines Norte and Masbate, 65 child miners were interviewed, and they described experiencing back pain, skin infections, and muscle spasms which are usual symptoms of mercury poisoning. ${ }^{47}$

\section{Gender Issues-Women Laborers}

According to the latest employment situation in the Philippines, there are 41.2 million Filipinos employed as of January 2021. Of these employed Filipinos, a total of 46.9\% (19.3 million) were women. ${ }^{48}$ Even though there is increased participation of women in the labor force, gender issues still exist, such as wage gap, discrimination, and workrelated health and safety issues. Four sectors were mentioned by the ILO to be significantly affected by the COVID-19 pandemic, namely accommodation and food services; real estate, business, and administrative activities; manufacturing; and the wholesale/retail trade. These are represented by 527 million women ( $41 \%$ of the world's total female employment), higher than their male counterparts suggesting more hits to them. This is especially felt in the low-income countries regarding the reduced working hours and cuts to wages and layoffs. ${ }^{48,49}$ The impositions of lockdowns and curfews and limited to no access to essential needs further worsen their living conditions. Furthermore, the said outbreak led the world to see the importance of the sectors providing critical services like health care, maintenance of communication and utilities, and emergency services participated by 96 million women. ${ }^{45}$

In the Philippines, a study among women workers in the business process outsourcing (BPO) sector showed women workers face general and specific health concerns. Public health issues include monotony of work, stress, negative work culture, and lack of promotion and career growth opportunities. On the other hand, specific health issues include eye strain, back pain, headache, and musculoskeletal and sleeping problems. Women workers, especially those employed in private households, also face a lack of social protection and are more likely to be exposed to verbal, physical, or sexual harassment. Moreover, women in the manufacturing sector experience occupational difficulties 
as they have lesser representation through unionization. Maintaining their work after childbirth also is a challenge. ${ }^{50}$

\section{Occupational Diseases and Hazards in Industries in the Philippines}

The Philippines had a total of 101,851 cases of occupational diseases across all industries in 2017. The sector with the highest cases of occupational diseases was administrative and support service activities $(31.8 \%, 32,344)$. This is followed by manufacturing $(28.9 \%, 29,458)$ and wholesale and retail trade industry with 9,733 cases (9.6\%). The sector with the least cases of occupational diseases, on the other hand, is the repair of computers and personal household goods $(0.1 \%, 138)^{15}$ (Table 4$)$.

According to the Philippine Business and Industry Census in 2017, the administrative and support service sectors had 8,471 establishments in the formal economy. Encompassed in this sector were activities related to employment placement agencies, call centers, and travel agency and tour operator activities. Employment placement agencies garnered the most significant number of establishments comprising $24.8 \%$

Table 4. Distribution of Occupational Diseases according to Major Industry Group, 2017

\begin{tabular}{|c|c|c|}
\hline Major Industry Group & 2017 & $\begin{array}{l}\text { Percent } \\
\text { share (\%) }\end{array}$ \\
\hline All Industries & 101,851 & 100.00 \\
\hline Agriculture, Forestry, and Fishing & 2,066 & 2.00 \\
\hline Mining and Quarrying & 1,660 & 1.60 \\
\hline Manufacturing & 29,458 & 28.90 \\
\hline $\begin{array}{l}\text { Electricity, Gas, Steam, and Air Conditioning } \\
\text { Supply }\end{array}$ & 894 & 0.90 \\
\hline $\begin{array}{l}\text { Water Supply; Sewerage, Waste } \\
\text { Management, and Remediation Activities }\end{array}$ & 366 & 0.36 \\
\hline Construction & 2,886 & 2.80 \\
\hline $\begin{array}{l}\text { Wholesale and Retail Trade; Repair of Motor } \\
\text { Vehicles and Motorcycles }\end{array}$ & 9,733 & 9.60 \\
\hline Transportation and Storage & 2,379 & 2.30 \\
\hline Accommodation and Food Service Activities & 2,388 & 2.30 \\
\hline Information and Communication & 2,431 & 2.40 \\
\hline Financial and Insurance Activities & 4,311 & 4.20 \\
\hline Real Estate Activities & 566 & 0.60 \\
\hline $\begin{array}{l}\text { Professional, Scientific, and Technical } \\
\text { Activities }\end{array}$ & 964 & 0.90 \\
\hline Administrative and Support Service Activities & 32,344 & 31.80 \\
\hline Education Except for Public Education & 4,201 & 4.10 \\
\hline $\begin{array}{l}\text { Human Health and Social Work Activities } \\
\text { Except for Public Health Activities }\end{array}$ & 3,523 & 3.50 \\
\hline Arts, Entertainment and Recreation & 1,542 & 1.50 \\
\hline $\begin{array}{l}\text { Repair of Computers and Personal and House- } \\
\text { hold Goods; Other Personal Service Activities }\end{array}$ & 138 & 0.10 \\
\hline
\end{tabular}

Note: Details may not add up to totals due to rounding.

Source: Adapted from Philippine Statistics Authority, 2017/2018 Integrated Survey on Labor and Employment, 2020 of the total percentage, followed by call centers and other related activities (14.9\%). ${ }^{51}$

This sector generated 1,430,520 employees in 2018. Call centers employed the highest number of workers at 631,400. Followed by temporary employment agency activities with 384,600 workers, then private security agencies with 124,028 workers $(11.8 \%) .^{51}$

The call center industry has boomed since 2007, making the Philippines the call center hub of the world. However, occupational health and safety concerns also emerged, including computer-related health disorders, hearing and voice problems associated with calls, prolonged night work or shift work, and work stress. ${ }^{52}$ Among all industries in the Philippines, call center activities had the highest number of cases $(31,270)$ of occupational diseases in 2015 . By type of disease, workers in call centers usually suffer from back pain (23.8\%), followed by occupational lung disease (16.8\%), occupational asthma (13.8\%), work-related musculoskeletal disorders (12\%), neck-shoulder pain (10.9\%), essential hypertension (10.0\%), and other occupational diseases (12.8\%) (Table 5). The nature of the job among call center agents, including prolonged sitting and repetitive work resulting in physical and psychological stress, may be associated with increased occupational diseases..$^{53}$ To provide services to international clients with different time zones, it is not uncommon for Filipino call center workers to work at graveyard shifts. This consequently affects their health, by which sleep disturbances or disorders and fatigue are commonly reported. Besides this, safety is also a concern, especially when commuting to and from work at late hours since many are being mugged during their commute. ${ }^{54}$

\section{Manufacturing}

The manufacturing industry, consisting of about 28,968 establishments in 2018, is one of the significant contributors to the Philippines' economy. It is one of the leading industries generating employment across the country as it employs 1,260,512 workers as of 2018. Manufacturing

Table 5. Cases of Occupational Diseases in Call Center Activities according to Type, 2015

\begin{tabular}{lrc}
\multicolumn{1}{c}{$\begin{array}{c}\text { Type of Occupational Diseases } \\
\text { in Call Center Activities }\end{array}$} & Number & Percentage \\
\hline Total & 31,270 & 100.0 \\
Back pain & 7,428 & 23.8 \\
Occupational lung diseases & 5,266 & 16.8 \\
Occupational asthma & 4,305 & 13.8 \\
Other work-related musculoskeletal & 3,745 & 12.0 \\
diseases & & \\
Neck-shoulder pain & 3,410 & 10.9 \\
Essential hypertension & 3,124 & 10.0 \\
Other occupational diseases & 3,992 & 12.8 \\
\hline
\end{tabular}

Source: Adapted from Philippine Statistics Authority, Integrated Survey on Labor and Employment, 2018 
establishments with the highest number of employed workers were the manufacture of food products (151,514 workers), Manufacture of electronic components (142,340 workers), and Manufacture of wearing apparel, except fur apparel (98,868 workers) amongst others. ${ }^{55}$

As employment increases in the manufacturing industry, the health and safety of workers must still be kept in mind, especially that there will be higher chances of it being overlooked since the focus of management would be on meeting the increasing demands of a global and competitive market. A local study in the country described the healthy work environment and health concerns among workers $(n=275)$ in an electronic manufacturing company. Said study showed that workers have health concerns in areas of illumination (i.e., eye fatigue), noise (i.e., tinnitus), temperature, and ventilation (i.e., dehydration). Some of the workers even reported occupational stress and occasional accidents such as slips and falls. ${ }^{56} \mathrm{In}$ a review done by OHSE, it was found that the manufacturing sector has the highest number of medical reimbursements claims from 2012-2017, and the majority of them are from the laborers with usual reports of end-stage renal (genitourinary diseases)..$^{57}$

\section{Wholesale and retail trade}

The administrative and support service activities sector held 137,674 establishments. Encompassed in this sector were activities related to the retail sale of other goods in specialized stores and retail sale of other household equipment in specialized stores. Retail sale of other goods in specialized stores garnered the most significant number of establishments comprising 28.8\% $(n=39,585)$ of the total percentage. This was followed by the retail sale of other household equipment in specialized stores at $12.6 \%$ or 17,389 establishments and retail sales in non-specialized stores at $9.8 \%$ or 13,478 establishments. This sector generated $1,410,967$ employees in 2018. Retail sale of other goods in specialized stores employed the highest number of workers at 276,442 . Followed by retail sales in non-specialized stores with 245,299 workers, then the retail sale of other household equipment in specialized stores with 170,220 workers. ${ }^{58}$ Workers in the sales industry usually stand during their entire shift; this is also the same case in factory workers. ${ }^{59} \mathrm{In}$ a study regarding the relationship of prolonged standing and musculoskeletal symptoms, prolonged standing is experienced by $70 \%$ of the respondents; $86 \%$ of all respondents also have musculoskeletal symptoms and commonly associated with the upper back, shoulders, and lower back. ${ }^{60}$

\section{Education}

All private education establishments by industry subclass held 14,576 establishments. This sector encompasses private general secondary education, private pre-primary/ pre-school and primary/elementary education for children without special needs, private higher education, and other private education-related industries. A little less than a quarter of this is on secondary/high school education (23.4\%; $n=3,409)$, followed by private primary/elementary education at $21.4 \%$ or 3,125 establishments. Third on the list is the pre-primary/pre-school education at $20.8 \%$ or 3,025 establishments. ${ }^{61}$ This sector generated 412,077 employees in 2018. Higher education employed the highest number of workers at 186,373 . This was followed by secondary/ high school education with 110,142 workers, then private primary/elementary education with 32,738 workers. ${ }^{61}$

A local study showed that employees in the academe or universities suffer from several occupational hazards and risks, including ergonomic, chemical, physical, and psychosocial hazards. The study found that employees experienced ergonomic hazards from manual handling, workplace structure, and visual display units (VDUs). Among the reported health illnesses were repetitive strain injuries (RSIs) and work-related musculoskeletal disorders (MSDs) accompanied by adverse health symptoms such as asymmetric shoulders/poor posture, tingling sensation at fingertips, joint restriction, visual fatigue, and pain in upper extremities and digits, amongst others. ${ }^{62}$ Musculoskeletal disorders were prevalent among schoolteachers; back pain was a frequent complaint of primary and secondary educators in the Philippines and Brazil. ${ }^{63}$ Lower back pain was positively correlated with being female, having a previous back injury, awkward arm position, and high work demand, while it was negatively associated with regular physical activity. ${ }^{64} \mathrm{It}$ was also found that workload and extrinsic satisfaction in their job influence the likelihood of having work-related musculoskeletal disorders (WMSD), with those less satisfied and have more workload more likely to have WMSDs. ${ }^{65}$

\section{Agriculture, forestry, and fishing industry}

The agriculture, forestry, and fishing sector held 3,285 establishments. This sector encompassed activities in animal production, growing of perennial and non-perennial crops, fishing, aquaculture. Animal production garnered the most number at $48.5 \%$ or 1,593 establishments. This is followed by growing of non-perennial $(15.2 \% ; n=500)$ and perennial crops $(10.4 \% ; n=341) .{ }^{66}$ This sector generated 154,910 employees in 2018. Growing perennial crops employed the highest number of workers $(n=59,644)$, followed by growing animal production with 37,618 workers, then growing nonperennial crops with 25,351 workers (16.7\%). ${ }^{66}$ Workers in agriculture, forestry, and fishing experience a wide array of occupational hazards compromising their health. These economic activities are one of the most hazardous jobs in the country. They are usually informal and characterized by poor working conditions that threaten the health and safety of workers. As of late, $59.1 \%$ of workers in this sector acquired occupational injuries due to stepping on, striking against, or being struck by objects. Usage of hand tools (37.9\%) also increased their prevalence of acquiring work-related injuries. ${ }^{15}$ In a study by Lu, Filipino farmers reported their common health complaints, which were headaches (69.4\%) 
and dizziness (41.0\%) usually experienced after pesticide exposure..$^{20}$ Respiratory health was also compromised, and related health symptoms reported were cough (39.4\%), difficulty breathing (15.6\%), breathlessness (14.9\%), and presence of pulmonary secretions (13.3\%). Among the hazards and risks of agriculture are occupational injuries (that may cause permanent or temporary incapacity and even death), occupational respiratory diseases, noise-induced hearing loss, dermal diseases, or even cancer that may be due to acute or chronic exposure from biological, chemical, physical, and extreme temperature hazards. ${ }^{67}$ Not only are the workers of agriculture affected but their families and communities as well. This is so because pesticide residues were seen in crops in the country, and some of them even exceeded the maximum residue limits (MRLs) set by the European Union. ${ }^{21}$ Heat stroke is also likely to happen due to prolonged exposure of farmers under the sun. ${ }^{68}$ With the continuous increase of environmental temperature due to climate change, farmers and fisherfolks also have increased vulnerability to "climatesensitive" illnesses, such as heat stress and heat stroke, because of their prolonged exposure to the heat of the sun. ${ }^{69}$

Back pain was the leading occupational disease in 2017. It was prevalent among workers engaged in manual labor and prolonged sitting, such as administrative and support services and manufacturing. Other common occupational diseases in 2017 were essential hypertension $(15.5 \%, 15,809)$, neck and shoulder pain $(11.4 \%, 11,576)$, occupational asthma $(5.4 \%, 5,506)$ and other infections $(5.3 \%, 5,394)$. The least common occupational diseases were occupational kidney disease $(0.3 \%)$, cataract $(0.3 \%)$, and chilblain, frostbite, and freezing $(0.2 \%)^{15}$ (Tables 6 and 7$)$.

\section{Occupational Safety and Health Standards and Programs in Philippine Industries.}

Almost all of the establishments in 2017 (31,675 out of 32,$288 ; 98.1 \%$ ) conducted several preventive and control

Table 6. Distribution of Cases of Back Pain by Industry Type, 2017

\begin{tabular}{|c|c|c|c|}
\hline Rank & $\begin{array}{l}\text { Type of industry with } \\
\text { complaints of back pain }\end{array}$ & Number & $\begin{array}{c}\text { Percent } \\
\text { share (\%) }\end{array}$ \\
\hline & Total cases of back pain & 31,903 & 100.0 \\
\hline 1 & $\begin{array}{l}\text { Administrative and support service } \\
\text { activities }\end{array}$ & 10,156 & 31.8 \\
\hline 2 & Manufacturing & 9,456 & 29.6 \\
\hline 3 & $\begin{array}{l}\text { Wholesale and retail trade; repair of } \\
\text { motor vehicles and motorcycles }\end{array}$ & 3,941 & 12.4 \\
\hline 4 & Education except for public education & 1,433 & 4.5 \\
\hline 5 & $\begin{array}{l}\text { Accommodation and Food Service } \\
\text { Activities }\end{array}$ & 1,031 & 3.2 \\
\hline 6 & Other industries & 5,886 & 18.4 \\
\hline
\end{tabular}

Note: Details may not add up to totals due to rounding.

Source: Adapted from Philippine Statistics Authority, 2017/2018 Integrated Survey on Labor and Employment, 2020 measures or activities in the interest of protecting their employees from preventable occupational hazards. Posting of safety signages or warnings (86.4\%) in the establishment was the most common preventive and control measure practiced. This was followed by smoke-free workplace (85.4\%), emergency preparedness and response activities for earthquake, fire, chemical spills, etc. (84.2\%), appointed safety or health officers, first aiders $(81.3 \%)$ or both, and regular inspection and maintenance of equipment $(80.4 \%)^{15}$ (Table 8).

Out of the total 32,288 establishments, 30,770 or 95.3\% implemented occupational safety and health policies and programs to ensure compliance and protection of employees. Most establishments conducted fire prevention and control programs at $82.6 \%$, followed by drug-free workplace policy and programs at $77.0 \%$, and emergency response preparedness programs at $75.1 \%$. Other prioritized OSH-related policies and programs were the accident prevention program (68.4\%) and monitoring or surveillance of occupational and work-related injuries $(63.5 \%)^{26}$ (Table 8). There were 22,303 out of the 32,288 total establishments (69.1\%) that conducted OSH-related training or seminars. The top OSH-related training or seminar conducted among establishments was the fire safety training at $51.9 \%$. This

Table 7. Distribution of Occupational Diseases according to Type of Disease, 2017

\begin{tabular}{|c|c|c|}
\hline Type of Disease & 2017 & $\begin{array}{c}\text { Percent } \\
\text { share }\end{array}$ \\
\hline Total & 101,851 & 100.0 \\
\hline Back Pain & 31,903 & 31.3 \\
\hline Essential Hypertension & 15,806 & 15.5 \\
\hline Neck-shoulder Pain & 11,576 & 11.4 \\
\hline Occupational Asthma & 5,506 & 5.4 \\
\hline Other Infections & 5,394 & 5.3 \\
\hline Occupational Dermatitis & 5,349 & 5.3 \\
\hline Other Work-Related Musculoskeletal Diseases & 5,188 & 5.1 \\
\hline Other Diseases & 4,748 & 4.7 \\
\hline Tuberculosis & 3,466 & 3.4 \\
\hline Shoulder Tendinitis & 3,244 & 3.2 \\
\hline Other Diseases Caused by Chemicals & 2,570 & 2.5 \\
\hline Carpal Tunnel Syndrome & 1,982 & 1.9 \\
\hline Heat, Stroke, Cramps, Exhaustion & 1,309 & 1.3 \\
\hline Occupational Lung Diseases & 1,309 & 1.3 \\
\hline Cardiovascular Disease & 987 & 1.0 \\
\hline Deafness & 596 & 0.6 \\
\hline Occupational Kidney Disease & 351 & 0.3 \\
\hline Cataract & 313 & 0.3 \\
\hline Chilblain, Frostbite, Freezing & 253 & 0.2 \\
\hline
\end{tabular}

Note: Details may not add up to totals due to rounding.

Source: Adapted from Philippine Statistics Authority, 2017/2018 Integrated Survey on Labor and Employment, 2020 
was followed by 40-hour basic occupational safety and health training (41.9\%), emergency preparedness and response (32.3\%), drug-free workplace training (24.6\%), and smokefree or tobacco-controlled workplace $(21.5 \%)$. The Bureau of Fire Protection (BFP) conducted several OSH-related training or seminars in $45.1 \%$ or 14,562 . On the other hand,
$39.2 \%$ of the establishments which conducted OSH training were started by their own company. Other functioning agencies were the OSHNet (24.5\%), DOLE accredited safety training organization (14.9\%), and DOLE regional or provincial office $(14.6 \%)^{15}$ (Table 8$)$.

Table 8. Distribution of OSH Programs in Industries and Establishments, 2017

\begin{tabular}{|c|c|c|c|}
\hline Rank & Preventive $\&$ control measure/ activities & Number of establishments & Percent share (\%) \\
\hline & Total establishments & 32,288 & 100.0 \\
\hline & Total establishments that conducted preventive and control measures or activities & 31,675 & 98.1 \\
\hline 1 & Posting of safety signages or warnings & 27,897 & 86.4 \\
\hline 2 & Smoke-free workplace & 27,574 & 85.4 \\
\hline 3 & Emergency preparedness \& response activities for earthquake, fire, chemical spills, etc. & 27,186 & 84.2 \\
\hline 4 & Appointed safety or health officers and/or first aiders & 26,250 & 81.3 \\
\hline 5 & Regular inspection and maintenance of equipment & 25,960 & 80.4 \\
\hline Rank & OSH policies or programs implemented & Number of establishments & Percent share (\%) \\
\hline & Total establishments & 32,288 & 100.0 \\
\hline & Total establishments that implemented OSH policies or programs & 30,770 & 95.3 \\
\hline 1 & Fire prevention and control program & 26,670 & 82.6 \\
\hline 2 & Drug-free workplace policy and program & 24,862 & 77.0 \\
\hline 3 & Emergency response preparedness program & 24,248 & 75.1 \\
\hline 4 & Accident prevention program & 22,085 & 68.4 \\
\hline 5 & Monitoring/surveillance of occupational and work-related injuries and illnesses & 20,503 & 63.5 \\
\hline Rank & OSH training or seminars & Number of establishments & Percent share (\%) \\
\hline & Total establishments & 32,288 & 100.0 \\
\hline & Total establishments with OSH training or seminars & 22,303 & 69.1 \\
\hline 1 & Fire safety training & 16,756 & 51.9 \\
\hline 2 & 40-hour basic occupational safety and health training & 13,527 & 41.9 \\
\hline 3 & Emergency preparedness and response & 10,413 & 32.3 \\
\hline 4 & Drug-free workplace training & 7,937 & 24.6 \\
\hline 5 & Smoke-free workplace or tobacco control in the workplace & 6,958 & 21.5 \\
\hline Rank & Conducting agency & Number of establishments & Percent share (\%) \\
\hline & Total establishments & 32,288 & 100.0 \\
\hline & Total establishments with OSH training or seminars & 22,303 & 69.1 \\
\hline 1 & Bureau of Fire Protection (BFP) & 14,562 & 45.1 \\
\hline 2 & Own company & 12,657 & 39.2 \\
\hline 3 & Occupational Safety and Health Center/OSHNEt & 7,911 & 24.5 \\
\hline 4 & DOLE Accredited Safety Training Organizations & 4,811 & 14.9 \\
\hline 5 & DOLE Regional/Provincial Office & 4,714 & 14.6 \\
\hline Rank & Designated personnel & Number of establishments & Percent share (\%) \\
\hline & Total establishments & 32,288 & 100.0 \\
\hline & Total establishments with designated health and safety personnel & 27,671 & 85.7 \\
\hline 1 & Trained first-aiders & 26,250 & 81.3 \\
\hline 2 & Safety officer & 14,917 & 46.2 \\
\hline 3 & Occupational health nurse & 8,072 & 25.0 \\
\hline 4 & Occupational health physician & 5,231 & 16.2 \\
\hline 5 & Dentist & 2,002 & 6.2 \\
\hline 6 & Industrial Hygienist & 226 & 0.7 \\
\hline
\end{tabular}

Source: Philippine Statistics Authority, Integrated Survey on Labor and Employment, 2020 
Out of the 32,288 total establishments, 27,671 or $85.7 \%$ provided designated health and safety personnel to protect the welfare of their employees. The majority of establishments hired trained first-aiders (81.3\%), followed by safety officers (46.2\%), occupational health nurses (25.0\%), occupational health physicians (16.2\%), dentists (6.2\%), and industrial hygienists (0.7\%). ${ }^{15}$ (Table 8) In a study done under OSHC, 3 of 4 participating television and broadcasting networks have their respective safety and health committees with occupational health personnel. The personnel include first aiders, nurses, and physicians. ${ }^{70}$ In a separate study, only $45 \%$ of responding supermalls and supermarkets in NCR have safety and health committees and rely on Human Resource departments to create health programs for contractors and sub-contractors. ${ }^{71}$

\section{DISCUSSION}

The study has shown that threats to the health and safety of workers in the Philippines exist in various sectors. Informal, marginalized workers or both are even disproportionately threatened due to multiple factors putting them at risk of occupational diseases and accidents. Globally, an estimated 2.78 million people die due to occupational diseases and accidents, while nonfatal ones leave around 374 million workers injured every year. ${ }^{2}$ These statistics are alarming and should be given more attention as occupational hazards affect not only workers and employers but also a country's productivity.

\section{OSH of various Occupational Groups and Categories}

According to the study results, there are specific occupational groups vulnerable to occupational hazards and risks. These are the workers in the informal sector and/or the marginalized groups such as construction workers, farmers, miners, and waste or garbage pickers. Occupational hazards exist in both formal and informal workers; however, the latter are more vulnerable because laws and policies protecting the safety and health of workers are almost nonexistent in the informal sector. They are also more prone to unknowingly violate basic health and safety precautions as they do not have enough workplace facilities (e.g., inaccessible basic services such as clean water and sanitation) and health education, unlike in the formal sector. ${ }^{72,73}$ These results are consistent with other studies stating that informal workers are more vulnerable to occupational accidents and diseases. For instance, informal waste workers were at high risk of acquiring work-related injuries due to unsafe work practices in Nepal. Some even acquire diseases that can be prevented through vaccinations showing their lack of protection towards preventable occupational diseases. ${ }^{74}$ In Pakistan, informal workers, particularly in the manufacturing and construction industries, were seen working in poor and unsafe conditions adjunct with exposure to noise, chemical, and ergonomic hazards. It was also realized that both employers and employees were not aware of maintaining a safe working environment. ${ }^{75}$ A mere well-established safety system does not work independently as safety knowledge and training are also essential in increasing occupational safety and health literacy. ${ }^{76-78}$

Another issue in the Philippines that needs to be tackled is the high prevalence of working children. The latest data on child labor revealed that around 1.3 million or $13.4 \%$ of the total Filipino children aged 5-17 years old were recorded to be engaged in different types of jobs, commonly in the agriculture, service, and industry sectors. ${ }^{42}$

Among the Philippine industries where child labor is rampant are mining and agricultural farming. ${ }^{79,80}$ One explanation of this is that agriculture and mining are considered familial jobs in the country where family members, including children, are expected to participate while their parents are working to help increase their family's income.

Wide gender gaps are also important matters to be discussed, especially in this modern era in which women's participation in work settings is increasing. This study cited examples of women workers under the threat of unsafe, unhealthy, and indecent work conditions. In the Philippines, there are multiple reports of women experiencing dangerous circumstances in their occupations. For instance, one report was about a woman working at a call center who was robbed, abused, and slain after getting off from work. ${ }^{81}$ In several studies on women workers, health illnesses were correlated with occupational risks, including unsafe work practices, overtime, and work environment stress, among others; $; 2,83$ women workers in the informal sector have it even worse as they were more vulnerable to exploitation. ${ }^{84}$

\section{Occupational Diseases and Hazards in the Philip- pines}

This study revealed that the top five industries with a high prevalence of occupational diseases were (1) administrative and support service activities, (2) manufacturing, (3) wholesale and retail trade; repair of motor vehicles and remediation activities, (4) financial and insurance activities, and (5) education except for public education. This can be backed up by the employment rates in January 2021, showing the sectors of services (57.2\%) and agriculture (24.4\%) to have some of the most significant numbers. ${ }^{13}$ It was also reported that $61.4 \%$ of the employed population work about 40 hours per week, resulting in various health and safety issues. ${ }^{13}$ The most common occupational diseases experienced by workers were back pain, essential hypertension, neck-shoulder pain, other musculoskeletal disorders, and occupational asthma.

Philippine manufacturing industries are associated with several occupational hazards, and even abroad, the manufacturing sector has a reputation of being dangerous in which workers need to take extra caution. For instance, in an international study on a rice mill manufacturing establishment, airborne hazards were caused by rice grain dust and noise hazards caused by rice mill machinery, ranging from 78-92 dBA. Rice grain dust may lead to adverse health symptoms 
affecting the visual (eye pain and irritation), integumentary (allergies), and respiratory systems. Occupational accidents commonly occur through slips and trips from rice grain dust, inadequate lighting, uncovered cables, obstructed view, and uneven walking paths. Being hit by falling objects may also be experienced by workers as objects are often stored above head level. ${ }^{85}$

\section{Occupational Safety and Health Standards and Programs in Philippine Industries}

With the presence of the COVID-19 pandemic, several standards and frameworks were made available to aid in the development of suitable policies in each country, like the Philippines, to prevent further risk exposure in the workplace. This includes the Occupational Safety and Health Convention, 1981 (No. 155), the Occupational Health Services Convention, 1985 (No. 161), the Promotional Framework for Occupational Safety and Health Convention, 2006 (No. 187). ${ }^{86}$ Specifically in the Philippines, the Department of Trade and Industry (DTI) and Department of Labor and Employment (DOLE) released a joint interim guideline to control and prevent the spread of COVID-19 in workplaces. This includes the proper usage of personal protective equipment, disinfection, and COVID-19 testing. ${ }^{87}$ With this, the Philippine Overseas and Employment Administration (POEA) also released Governing Board Resolution No. 13, Series of 2020, which includes guidelines for establishing "Green Lanes" to facilitate seafarers' fast and safe travel during the height of the pandemic. ${ }^{88}$

\section{CONCLUSION}

The study attempted to show a comprehensive review of available data on occupational safety and health in the Philippines, considering that there is limited data in the country regarding this subject. The study has shown that there are hazard exposures and illnesses among various occupational are beset with occupational diseases and injuries; and that the $\mathrm{OSH}$ programs in the industries in the country fall below the standard, and this necessitates the need for more aggressive crafting of policies and programs by both national government and the industries. The study further showed that different population groups and industries are threatened with unsafe and unhealthy conditions of the nature of their job and workplaces.

Countries worldwide are starting to recognize the importance of occupational safety and health, thus, integrating safety and health in many major industries. The Philippines must push harder to keep up with the development of other countries.

\section{Statement of Authorship}

The author conceptualized the work; acquisition and analysis of data; drafting and revising; and approved the final version to be published.

\section{Author Disclosure}

The author declared no conflicts of interest.

\section{Funding Source}

This study was carried out under the National Institutes of Health, University of the Philippines Manila.

\section{REFERENCES}

1. Torres EB, Greaves IA, Gapas JL, Ong TT. Occupational Health in the Philippines. Occup Med. 2002 Jul-Sep;17(3):455-68.

2. International Labour Organization. Safety and Health at the Heart of the Future of Work: Building on 100 Years of Experience [Internet]. Geneva: International Labour Organization; 2019 [cited 2020 Dec]. Available from: https://www.ilo.org/safework/events/safeday/ WCMS_686645/lang--en/index.htm.

3. World Health Organization. Protecting Workers' Health [Internet]. Geneva: World Health Organization; c2021 [updated 2017 Nov 30; cited $2021 \mathrm{Mar}$. Available from: http://www.who.int/news-room/ fact-sheets/detail/protecting-workers'-health.

4. Wolf J, Prüss-Ustün A, Ivanov I, Mugdal S, Corvalán C, Bos R, et al. Preventing Disease through a Healthier and Safer Workplace [Internet]. Geneva: World Health Organization; 2018 [cited 2020 Dec]. Available from: https://apps.who.int/iris/bitstream/hand le/10665/272980/9789241513777-eng.pdf?sequence=1\&isAllowed=y.

5. International Labor Organization. Working Together to Promote a Safe and Healthy Working Environment. International Labour Conference, 106th Session, 2017 [Internet]. 2017 [cited 2020 Dec]. Available from: https://www.ilo.org/wcmsp5/groups/public/---ed_ norm/---relconf/documents/meetingdocument/wcms_543647.pdf.

6. International Labour Statistics [Internet]. Geneva: International Labour Organization; c1996-2021 [cited 2020 Dec 5]. Safety and Health at Work in the Philippines; [about 2 screens]. Available from: https://www.ilo.org/manila/areasofwork/safety-and-health-at-work/ lang--en/index.htm.

7. Philippine Statistics Authority. Philippines Population Surpassed the 100 Million Mark (Results from the 2015 Census of Population) [Internet]. Quezon City: Philippine Statistics Authority; c2021 [updated 2017 Jun 30; cited $2021 \mathrm{Mar}$. Available from: http://www. psa.gov.ph/population-and-housing/node/120080.

8. Rafales A.PH Population to Reach 110.8 Million by 2021: POPCOM [Internet]. Quezon City: ABS-CBN Corporation; c2021. [updated 2020 Dec 30; cited $2021 \mathrm{Feb}$. Available from: https://www.google. $\mathrm{com} / \mathrm{amp} / \mathrm{s} /$ news.abs-cbn/amp/news/12/30/20/ph-population-toreach-1108-million-by-2021-popcom.

9. The World Bank [Internet]. Washington: The World Bank Group; 2021 [cited $2021 \mathrm{Mar}$. Philippines: Country Profile; [about 3 screens]. Available from: https://databank.worldbank.org/data/views/reports/ reportwidget.aspx?.

10. The World Bank [Internet]. Washington: The World Bank Group; 2021 [cited2021Mar].GDPgrowth(annual\%)-Philippines;[about3screens]. Available from: https://data.worldbank.org/indicator/NY.GDP. MKTP.KD.ZG?end=2019\&locations=PH\&start=1961\&view=chart.

11. Philippine Statistics Authority. Employment Situation in October 2020 [Internet]. Philippines: Philippine Statistics Authority; c2020 [updated 2020 Dec 3; cited 2021 Jan]. Available from: https://psa.gov. $\mathrm{ph} /$ content/employment-situation-october-2020.

12. Philippine Statistics Authority. Employment Situation in April 2020 [Internet]. Philippines: Philippine Statistics Authority; c2020 [updated 2020-b Nov 11; cited 2020 Dec]. Available from: https://psa.gov. $\mathrm{ph} /$ statistics/survey/labor-and-employment/labor-force-survey/title/ Employment\%20Situation\%20in\%20April\%202020\#: :text=a)\%20 The\%20labor\%20force\%20participation,33.8\%20million\%20total\%20 employed\%20persons.

13. Philippine Statistics Authority [Internet]. Employment Situation in March 2021. Philippines: Philippine Statistics Authority; c2021 
[updated 2021 May 6; cited 2021 May]. Available from: https:// psa.gov.ph/content/employment-situation-march-2021.

14. International Labour Organization [Internet]. Geneva: International Labour Organization; c2021 [cited $2021 \mathrm{Mar}$ ]. Informal economy in the Philippines; [about 3 screens]. Available from: https://www.ilo. $\mathrm{org} / \mathrm{manila} /$ areasofwork/informal-economy/lang--en/index.htm.

15. Department of Labor and Employment. Workers in the Informal Economy [Internet]. 2002 [cited $2021 \mathrm{Mar}$ ]. Available from: https:// www.dole.gov.ph/fndr/bong/files/Workers\%20in\%20the\%20 Informal\%20Economy.pdf.

16. Ocampo V. Informal Sector (conceptual definition). Philippine Statistics Authority [Internet]. 2017 [cited 2021 Mar]. Available from: https://psa.gov.ph/content/informal-sector-conceptual-definition.

17. Philippine Statistics Authority. Selected Statistics on Agriculture 2018 [Internet]. Quezon City: Philippine Statistics Authority; 2018 [cited 2021 Mar]. Available from: https://psa.gov.ph/sites/default/files/ Selected\%20Statistics\%20on\%20Agriculture\%202018.pdf.

18. CountrySTAT Philippines. Philippine Agriculture in Figures, 2017. Quezon City: Philippine Statistics Authority; c2020 [updated 2017; cited $2021 \mathrm{Mar}$. Available from: http://countrystat.psa.gov.ph/?cont=3.

19. Mohammad N, Abidin E, How V, Praveena S, Hashim Z. Pesticide Management Approach towards Protecting the Safety and Health of Farmers in Southeast Asia. Rev Environ Health. 2018 Jun 27;33(2):123-34.

20. Lu JL. 0007 Assessment of Pesticide Exposure and Occupational Safety and Health of Farmers in the Philippines. Occup Environ Med. 2017 Aug;74 Suppl 1:A1.

21. Lu JL. Insecticide Residues in Soil, Water, and Eggplant Fruits and Farmers' Health Effects due to Exposure to Pesticides. Environ Health Prev Med. 2015 Jan;20(1):53-62.

22. International Labour Organization. Farm Safety: A New Beginning [Internet]. Geneva: International Labour Organizationl; c2021 [updated 2018 Apr 23; cited 2021 Jan]. Available from: https://www. ilo.org/manila/publich/WCMS_629311/lang--en/index.htm.

23. Kaya Natin! Movement. Organic Farming Helps Lessen Health Risks in Cervantes, Ilocos Sur [Internet]. Philippines: Rappler; c2020 [updated 2018 Apr 21; cited 2021 Apr 5]. Available from: https://www. rappler.com/nation/organic-farming-less-health-risks-cervantesilocos-sur-benjamin-maggay.

24. Leonardo L, Rivera P, Saniel O, Solon JA, Chigusa Y, Villacorte E, et al. New Endemic Foci of Schistosomiasis Infections in the Philippines. Acta Trop. 2015 Jan; 141:354-60.

25. Soares Magalhães R, Salamat MS, Leonardo L, Gray D, Carabin H, Halton K, et al. Int J Parasitol. 2014 Nov; 4(13):977-84.

26. Leonardo L, Hernandez L, Magturo TC, Palasi W, Rubite JM, de Cadiz A, et al. Current Status of Neglected Tropical Diseases (NTDs) in the Philippines. Acta Trop. 2020 Mar; 203:105284. PubMed PMID: 31786109.

27. Bhatia R, Sharma K. Occupational Dermatoses: An Asian Perspective. Indian J Dermatol Venereol Leprol. 2017 Sep-Oct;83(5):525-35.

28. Cadiz A, Fadrilan-Camacho V, Quizon R, Josef R. Occupational Health and Safety of the Informal Mining, Transport and Agriculture Sectors in the Philippines. Southeast Asian J Trop Med Public Health. 2016 Jul;47(4):833-43.

29. Granadillos NG, Parafina CS. Assessment of Occupational Safety and Health Hazards Exposure of Workers in Small-scale Gold Mining in the Philippines [Internet]. Geneva: International Labour Organization; 2020 [cited 2021 Jan]. Available from: https://www. ilo.org/wcmsp5/groups/public/---asia/---ro-bangkok/---ilo-manila/ documents/publication/wcms_751885.pdf.

30. Lu JL. 0008 Occupational Epidemiology of Health Risks and Chemical Exposures among Small Scale Miners in the Philippines. Occup Environ Med. 2017-b;74 Suppl 1:A1.

31. Bautista DS, Rivera DC, Relenta FA. Study on the Occupational Safety and Health Profile of Selected Large Scale Surface Metallic and NonMetallic Mines in the Philippines. 2017 [cited 2021 Apr]. Available from: http://www.oshc.dole.gov.ph/images/NOSHCongress/3.STUDY-ON-THE-OCCUPATIONAL-SAFETY-ANDHEALTH-PROFILE-OF-SELECTED-LARGE-SCALE-
SURFACE-METALLIC-AND-NON-METALLIC-MINES-INTHE-PHILIPPINES.pdf.

32. Ibon Organization. Latest Mining Disaster Further Signal to Junk Mining Law [Internet]. Philippines: IBON.org; c2019 [updated 2015 Jul 19; cited $2021 \mathrm{Mar}$. Available from: http://ibon.org/2015/07/ latest-mining-disaster-further-signal-to-junk-mining-law/.

33. Al-Khatib IA, Al-Sari' MI, Kontogianni S. Assessment of Occupational Health and Safety among Scavengers in Gaza Strip, Palestine. J Environ Public Health. 2020 Feb 24;2020:3780431. PubMed PMID: 32184833.

34. United Nations Environment Programme (UNEP). Waste Management during the COVID-19 Pandemic: From Response to Recovery [Internet]. Nairobi: United Nations Environment Programme; 2020 [cited 2021 Mar]. Available from: https:// www.google.com/url?sa=t\&source=web\&rct=j\&url=https: // reliefweb.int/sites/reliefweb.int/files/resources/WMC-19. pdf\&ved=2ahUKEwj63oSRsOnvAhWad94KHd_cBL4QFjACegQI BhAC\&usg=AOvVaw1_9ws81ukjhz2gW3-FQmeY.

35. Gumasing MJ, Sasot ZB. An Occupational Risk Analysis of Garbage Collection Tasks in the Philippines. In: 2019 IEEE 6th International Conference on Industrial Engineering and Applications (ICIEA); 2019 Apr 12-15; Tokyo, Japan. Danvers: Institute of Electrical and Electronics Engineers, Inc.; 2019. p. 409-13.

36. Ta Wee S. Safety and Health Issues of Solid Waste Management in Developing Countries. Occup Med Health Aff. 2017;5(4 Suppl):33.

37. The World Bank. Philippines: 6000 Informal Garbage Workers to Benefit from Japanese Grant [Internet]. Washington: The World Bank Group; c2020 [upated 2012 Jun 18; cited 2020 Dec]. Available from: https://www.worldbank.org/en/news/press-release/2012/06/18/ philippines-6000-informal-garbage-workers-to-benefit-fromjapanese-grant.

38. Cruvinel VRN, Marques CP, Cardoso V, Novaes MRCG, Araújo WN, Angulo-Tuesta A, et al. Health Conditions and Occupational Risks in a Novel Group: Waste Pickers in the Largest Open Garbage Dump in Latin America. BMC Public Health. 2019 May 16;19(1):581.

39. Garcia C. Child Labor. Philippine Statistics Authority [Internet]. Philippines: Philippine Statistics Authority; 2021 [updated 2018; cited $2021 \mathrm{Mar}$. Available from: https://psa.gov.ph/content/child-labor-0.

40. Department of Labor and Employment. Profiling of Child Laborers Pushed [Internet]. Philippines: Philippine Information Agency; c2020 [updated 2018 April 9; cited 2020 Dec]. Available from: https://pia. gov.ph/news/articles/1006470.

41. Ordinario C. Millions of Children 5 to 17 Years Old Still WorkingPSA [Internet]. Makati City: BusinessMirror; c2021. [updated 2021 Feb 15; cited $2021 \mathrm{Mar}$. Available from: https://businessmirror. com.ph/2021/02/15/millions-of-children-5-to-17-years-old-stillworking-psa/.

42. Philippine Statistics Authority. Decent Work in the Philippines: Statistics on Working Children (3rd of a Series on Decent Work Statistics) Volume 23, No. 5 [Internet]. 2019 Apr [cited 2020 Dec]. Available from: https://psa.gov.ph/sites/default/files/LABSTAT\%20 Updates\%20Vol.\%2023\%20No.\%205\%20on\%20Decent $\% 20$ Work\%20in\%20the\%20Philippines\%20\%20Statistics\%20on\%20 Working\%20Children_0.pdf.

43. Philippine Statistics Authority. Estimated Number of Working Children 5 to 17 Years Old Who Worked during the Past Week was 3.3 Million (Final Results of the 2011 Survey on Children) [Internet]. Quezon City: Philippine Statistics Authority; c2021 [updated 2015 Dec 9;cited $2021 \mathrm{Mar}$. Available from: https://psa.gov.ph/content/ estimated-number-working-children-5-17-years-old-who-workedduring-past-week-was-33-million.

44. International Labour Organization. Global Estimates of Child Labour: Results and Trends, 2012-2016 [Internet]. Geneva: International Labour Organization; 2017 [cited 2021 Mar]. Available from https:/www.ilo.org/wcmsp5/groups/public/---dgreports/---dcomm/ documents/publication/wcms_575499.pdf.

45. International Labor Organization. COVID-19 Impact on Child Labour and Forced Labour: The Response of the IPEC+ Flagship Programme [Internet]. Geneva: International Labour Organization; 
2020 [cited 2021 Feb]. Available from: https://www.ilo.org/ wcmsp5/groups/public/---ed_norm/---ipec/documents/publication/ wcms_745287.pdf.

46. Shendell DG, Noomnual S, Chishti S, Sorensen Allaci MA, Madrigano J. Exposures Resulting in Safety and Health Concerns for Child Laborers in Less Developed Countries. J Environ Public Health. 2016; 2016:3985498. PubMed PMID: 27382374.

47. Human Rights Watch. "What ... if Something Went Wrong?" [Internet]. New York: Human Rights Watch; c2021 [updated 2015 Sep 29; cited 2021 Apr]. Available from: https://www.hrw.org/ report/2015/09/29/what-if-something-went-wrong/hazardous-childlabor-small-scale-gold-mining.

48. International Labour Organization. The COVID-19 Response: Getting Gender Equality Right for a Better Future for Women at Work [Internet]. Geneva: International Labour Organization; 2020b [cited $2021 \mathrm{Feb}$. Available from: https://www.ilo.org/manila/areasofwork/ equality-and-discrimination/WCMS_744685/lang--en/index.htm.

49. International Labor Organization. ILO Monitor: COVID-19 and the World of Work. Seventh Edition. Updated Estimates and Analysis [Internet]. 2021 [cited $2021 \mathrm{Feb}$ ]. Available from: https://www.ilo.org/ global/topics/coronavirus/impacts-and-responses/WCMS_767028/ lang--en/index.htm.

50. Asian Development Bank. Gender Equality in the Labor Market in the Philippines [Internet]. Manadaluyong City: Asian Development Bank; 2013 [cited 2021 Mar 30]. Available from: https://www.adb. $\mathrm{org} / \mathrm{sites} /$ default/files/publication/31194/gender-equality-labormarket-philippines.pdf.

51. Philippine Statistics Authority. 2018 Census of Philippine Business and Industry: Administrative and Support Service Activities [Internet]. Quezon City: Philippine statistics Authority; c2021 [updated 2021b Jan 13; cited $2021 \mathrm{Feb}$ ]. Available from: https:// psa.gov.ph/content/2018-census-philippine-business-and-industryadministrative-and-support-service-activities-0.

52. 2008: Policy Guidelines Governing the Occupational Safety and Health of Workers in the Call Center Industry and Technical Guidelines on Safety and Health for Call Centers. Department of Labor and Employment [Internet]. 2008 [cited $2021 \mathrm{Mar}$ ]. Available from http:// oshc.dole.gov.ph/images/Files/IEC\%20Materials/OSH\%20for\%20 Call\%20Center.pdf.

53. Philippine Statistics Authority. LABSTAT Updates: Safety and Health in the Workplace, Cases of Occupational Diseases (last of a 4-part series) Volume 22, No. 6 [Internet]. Quezon City: Philippine Statistics Authority; 2018-b [cited $2021 \mathrm{Mar}$. Available from: https:// psa.gov.ph/sites/default/files/LABSTAT\%20Updates\%20Vol\%20 22\%20No\%206_0.pdf.

54. Hechanova MR. The Call Center as a Revolving Door: A Philippine Perspective. Pers Rev. 2013 Apr 5;42(3):349-65.

55. Philippine Statistics Authority. 2018 Census of Philippine Business and Industry: Manufacturing [Internet]. 2020 Dec 3 [cited $2021 \mathrm{Feb}$ ]. Available from: https://psa.gov.ph/content/2018-census-philippinebusiness-and-industry-manufacturing.

56. De Chavez B, Malabanan E, Ramilo J, Sarapat H, Buluran R. Effects of Work Environment to the Health and Productivity of the Workers of IM Digital Philippines, Inc. LPU-Laguna Journal of Engineering and Computer Studies. 2015 Sep;3(1):85-95.

57. Environment Control Division. A Review of the Employees' Compensation Database on Medical Reimbursement Claims and its Potential Use as a Tool for the Prevention of Occupational Diseases [Internet]. 2018 [cited 2021 Apr]. Available from: https://oshc. dole.gov.ph/wp-content/uploads/2020/10/2018-A-Review-of-theEmployees-Compensation-Database-on-Medical-ReimbursementClaims-and-Its-Potential-Use-as-a-Tool-for-the-Prevention-ofOccupational-Diseases.pdf.

58. Philippine Statistics Authority. 2018 Census of Philippine Business and Industry: Wholesale and Retail Trade; Repair of Motor Vehicles and Motorcycle [Internet]. 2020 Dec 2 [cited 2021 Feb]. Available from: https://psa.gov.ph/content/2018-census-philippine-businessand-industry-wholesale-and-retail-trade-repair-motor.

59. House Bill No. 1049, 17th Cong., 1st Sess. (2016).
60. Occupational Safety and Health Center, Ateneo de Manila University. A Cross Sectional Study of the Relationship of Prolonged Standing and Musculoskeletal Symptoms among Sales Personnel (Ateneo and OSHC) [Internet]. 2015 [cited $2021 \mathrm{Apr}$. Available from: https:// oshc.dole.gov.ph/wp-content/uploads/2020/10/2011-2012-A-CrossSectional-Study-of-the-Relationship-of-Prolonged-Standing-2.pdf.

61. Philippine Statistics Authority. 2018 Census of Philippine Business and Industry: Education [Internet]. Quezon City: Philippine Statistics Authority; c2021 [updated 2021 Jan 28; cited 2021 Feb]. Available from: https://psa.gov.ph/content/2018-census-philippine-businessand-industry-education.

62. Saong M, Gacayan J, Marcelino C. Occupational Health and Safety Needs of Employees in an Academic Institution in Baguio City. Sukimat. 2016 Jan-Jun;2(1):93-117.

63. Erick PN, Smith DR. 2011. A Systematic Review of Musculoskeletal Disorders among School Teachers. BMC Musculoskelet Disord. 2011 Nov 17;12:260.

64. Erick PN, Smith DR. Low Back Pain among School Teachers in Botswana, Prevalence, and Risk Factors. BMC Musculoskelet Disord. 2014 Oct 30;15:359.

65. Florante JM, Rivera JD, Relente FA. Work-Related Injuries and Diseases among Filipino Seafarers: A Review of Employees' Compensation Claims from the Social Security System, 2013-2014 [Internet]. 2017 [cited $2021 \mathrm{Apr}$ ]. Available from: https://oshc.dole. gov.ph/wp-content/uploads/2020/10/2017-Work-Related-Injuriesand-Diseases-Among-Filipino-Seafarers-A-Review-of-EmployeesCompensation-Claims-from-the-Social-Security-System-2013-2014. pdf.

66. Philippine Statistics Authority. 2018 Census of Philippine Business and Industry: Agriculture, Forestry, and Fishing [Internet]. 2020-f Nov 9 [cited 2021 Feb]. Available from: https://psa.gov.ph/content/2018census-philippine-business-and-industry-agriculture-forestry-andfishing-0.

67. Cadiz A, Fadrilan-Camacho V, Quizon R, Josef R. Occupational Health and Safety of the Informal Mining, Transport and Agriculture Sectors in the Philippines. Southeast Asian J Trop Med Public Health. 2016 Jul;47(4):833-43.

68. Pasiona S. Health Expert Warns Farmers against Heatstroke [Internet]. Muñoz: Philippine Rice Research Institute; c2021 [updated 2016 Mar 12; cited $2021 \mathrm{Mar}$. Available from: http://www.philrice.gov.ph/ health-expert-warns-farmers-heat-stroke/.

69. Limayo KL. Filipino Farmers, Fisherfolk Most Vulnerable to Heatrelated Illnesses Due to Climate Change [Internet]. Pasig City: Rappler; c2021 [updated 2020 May 23; cited 2021 Apr]. Available from: https://r3.rappler.com/science-nature/environment/252201filipino-farmers-fisherfolk-vulnerable-heat-related-illneses-climatechange.

70. Occupational Safety and Health Center. A Case Report on the Occupational Safety and Health Perspectives in the Philippine Television and Broadcasting Industry [Internet]. 2016 [cited 2021 Apr]. Available from: https://oshc.dole.gov.ph/wp-content/ uploads/2020/10/2016-OSHC-TV-and-Broadcasting-IndustryCase-Report-5.pdf.

71. Occupational Safety and Health Center (OSHC). Study on the Occupational Safety and Health Status of Contractors and SubContractors of Supermalls and Supermarkets in the National Capital Region to Identify the Gaps in the Implementation of Occupational Safety [Internet]. 2015 [cited 2021 Apr]. Available from: https:// oshc.dole.gov.ph/wp-content/uploads/2020/10/2015-Study-On-TheOccupational-Safety-And-Health-Status-Of-Contractors-And-SubContractors-Of-Supermalls-And-Supermarkets-In-The-NationalCapital-Region-1.pdf.

72. International Labour Organization. Farm safety: A New Beginning [Internet]. Geneva: International Labour Organization; c1996-2020 [updated 2018 Apr 23; cited 2020 Dec]. Available from: https://www. ilo.org/manila/public/WCMS_629311/lang--en/index.htm.

73. Tubis A, Werbi'nska-Wojciechowska S, Wroblewski A. Risk Assessment Methods in Mining Industry-A Systematic Review. Appl Sci. 2020 Jul 28;10:5172. 
74. Black M, Karki J, Lee ACK, Makai P, Baral YR, Kritsotakis EI, et al. The Health Risks of Informal Waste Workers in the Kathmandu Valley: A Cross-sectional Survey. Public Health. 2019 Jan;166:10-18.

75. Ahmed I, Usman A, Nazir MS, Shaukat MZ. Safety Practices in the Informal Industrial Segment of Pakistan. Saf Sci. 2018 Dec;110 (Pt A):83-91.

76. Coman MA, Marcu A, Chereches RM, Leppälä J, Van Den Broucke S. Educational Interventions to Improve Safety and Health Literacy Among Agricultural Workers: A Systematic Review. Int J Environ Res Public Health. 2020 Feb 10;17(3):1114.

77. Idoga PE. Analysis of Factors Affecting the Health and Safety of Construction Workers. In: 5th International Project and Construction Management Conference (IPCMC 2018); 2018 Nov 16-18; Cyprus: Cyprus International University; 2018. p. 1345-52.

78. Liu S, Nkrumah ENK, Akoto LS, Gyabeng E, Nkrumah E. The State of Occupational Health and Safety Management Frameworks (OHSMF) and Occupational Injuries and Accidents in the Ghanaian Oil and Gas Industry: Assessing the Mediating Role of Safety Knowledge. Biomed Res Int. 2020 Mar 13;20:6354895. PubMed PMID: 32258132.

79. Childfund International Organization [Internet]. Richmond: ChildFund; c2021 [cited 2021 Mar]. Unseen Workers: Child Labor in the Philippines; [about 3 screens]. Available from: https://www. childfund.org/child-labor-in-the-philippines/?no_redirect=true.

80. Ecumenical Institute for Labor Education and Research (EILER) [Internet]. Philippines: Ecumenical Institute for Labor Education and Research, Inc.; c2021 [cited $2021 \mathrm{Mar}$. Child labor in the Philippines; [about 3 screens]. Available from: https://eiler.ph/childlabor-in-the-philippines/.

81. Jimenez J. Night Call Centers, Hazardous to Female Workers [Internet]. Quezon City: Trade Union Congress of the Philippines (TUCP); c2019 [updated 2017 May 11; cited 2021 Jan]. Available from: http://tucp.org.ph/2017/05/night-call-centers-hazardousfemale-workers/.
82. Shan Z, Li Y, Zong G, Guo Y, Li J, Manson JE, et al. Rotating Night Shift Work and Adherence to Unhealthy Lifestyle in Predicting Risk of Type 2 Diabetes: Results from Two Large US Cohorts of Female Nurses. BMJ. 2018 Nov 21;363:k4641. PubMed PMID: 30464025.

83. Meeker BJ, Carruth A, Holland CB. Health Hazards and Preventive Measures of Farm Women. Emerging issues. AAOHN J. 2002 Jul;50(7):307-14.

84. Panikkar B, Brugge D, Gute DM, Hyatt RR. "They See Us As Machines:" The Experience of Recent Immigrant Women in the Low Wage Informal Labor Sector. PLoS One. 2015 Nov 24;10(11):e0142686. PubMed PMID: 26600083.

85. Yee LH, Abu AL-Rejal H. Occupational Safety and Health Practices in the Manufacturing Industry. In: Hami N, Yamin FM, Abidin R, Ahmad Zaidi MF, Ahmad A, Zainuddin N, Radzuan K, et al., editors. In: Proceedings of Symposium on Technology Management \& Logistics; 2016 Dec 6-7; Sintok: STML, UUM COB, UUM; 2016. p. 782-92.

86. International Labour Organization. ILO Standards and COVID-19 (Coronavirus) FAQ. Geneva: International Labour Standards Department; 2021-b [cited $2021 \mathrm{Mar}$. Available from: https://www. ilo.org/wcmsp5/groups/public/@ed_norm/@normes/documents/ publication/wcms_780445.pdf.

87. Department of Labor and Employment. DTI and DOLE Interim Guidelines on Workplace Prevention and Control of COVID-19 [Internet]. 2020 May 1 [cited 2021 Mar]. Available from: https://www. dole.gov.ph/news/dti-and-dole-interim-guidelines-on-workplaceprevention-and-control-of-covid-19/.

88. Philippine Overseas Employment Administration. Governing Board Resolution No. 13, Series of 2020 [Internet]. 2020 [cited 2021 Mar]. Available from: https://www.poea.gov.ph/gbr/2020/GBR-13-2020. pdf. 